\title{
PRIESTOR A JEHO REKVIZITY AKO SYMPTÓMY SLOVENSKEJ A ČESKEJ LITERÁRNEJ MODERNY
}

\author{
ZUZANA CHRENKOVÁ
}

CHRENKOVÁ, Zuzana: Space and Its Props as Symptoms of Slovak and Czech Literary Modernism, 2019, Vol. 1, Issue 1, pp. 57 - 68. DOI: 10.17846/CEV.2019.01.1.57-68.

\begin{abstract}
In the contribution we focus on defining the character of the compositional category of space and its props in selected literary texts of Slovak and Czech interwar prose, and we follow the need to incorporate the symptoms of Slovak and Czech modernism into the Central European area as mutually identifying contexts.
\end{abstract}

KEYWORDS: Space. Props. Movement. Jozef Cíger Hronský. Jan Weiss.

Zmenené podmienky pre formovanie jednotlivých národov stredoeurópskeho priestoru po roku 1918 - osobitne slovenskej a českej národnej a kultúrnej identity v novom štátnom útvare - mali svoj pendant aj v špecifickosti kultúr, rozdielnosti štýlu, a teda v pluralitnom charaktere umenia vôbec. Odpútanie umeleckej produkcie od jej predchádzajúcej súvztažnosti s národnými programami ${ }^{1}$ umožnilo istú sebaidentifikáciu, uvedomovanie si autentickej podoby slovenskej a českej literárnej tvorby, a to práve cez výpovednú hodnotu umeleckých diel-artefaktov v autorstve výrazných individualít. S vymedzením literárneho vývinu v rokoch 1918 - 1939 ako obdobia poetologicky či smerovo nejednotného paralelne súvisí aj priradenie určitých špecifík konkrétnych literárnych textov k symptómom slovenskej ${ }^{2}$ a českej ${ }^{3}$ literárnej moderny. Kompozičné kategórie

1 O. Čepan hovorí o jednej z funkcií predprevratového umenia, ktorú stotožňuje s vyjadrením a propagáciou národných ideí, pričom „všetko ,politické a ideologické sa bezo zvyškov nepretavilo na ,estetické (Čepan 1973, 267).

2 Významový rámec pojmu moderna presahuje ukotvenost v jedinej vednej disciplíne a rovnako aj literárnovedné prístupy k slovenskej literárnej moderne sa odlišujú - bud’ sa v rôznej miere dopíňajú, dokonca sa mnohé z nich vylučujú. Za exemplárny príklad interpretačnej nejednotnosti uvádzame koncepciu M. Gáfrika, ktorý slovenskú literárnu modernu charakterizuje ako „model kukučínovského realizmu“ (Gáfrik 1993, 4) s časovým rozpätím r. 1900 - 1918. Zatial čo M. Bátorová považuje literárnu modernu za „novoromantický smer“ (Bátorová 2011a, 24), ktorého uplatnenie presahuje striktnú časovú chronológiu, pretože určenie podstaty moderny z filozofických konceptov siaha až do karteziánskeho obdobia, teda do času, $\mathrm{v}$ ktorom dochádza $\mathrm{k}$ zmene pozície človeka vo vztahu $\mathrm{k}$ Bohu, sebe i celému svetu, o čom vypovedá samotná téza Cogito ergo sum ako princíp zo seba vychádzajúceho myslenia. M. Bátorová tak explikuje pojem moderna podla W. Welscha, ktorý popri novovekej moderne rozlišuje ešte radikálnu modernu 20. storočia, kde už klíči postmoderna (Bátorová 2018b, 205).

3 Pojem česká moderna sa v českom literárnovednom prostredí tradične vztahuje k 90. rokom 19. storočia, s čím primárne súvisí vystúpenie generačnej skupiny zduženej pod Manifestom České moderny (1895), avšak $\mathrm{k}$ relativizovaniu jednotného významu spojenia česká moderna dochádza aj v tomto priestore (J. Máchal vyčleňuje českú modernu rokmi 1880 - 1900, A. Novák nepoužíva tento pojem ako pojem periodizácie, F. Buriánek zase vymedzuje českú modernu ako označenie pre literatúru 90. rokov, aby zdôraznil jej typologickú identitu s európskym moderným umením konca 19. storočia) (Balabanovová 1989, 594). No diferentný prístup k českej moderne v porovnaní s predchádzajúcimi konceptami vytvára V. Papoušek, a to vymedzením klúčového spojenia nová moderna, ktorú stavia proti moderne z prelomu storočí. V trojzväzkovom diele Dějiny nové moderny kolektív autorov identifikuje českú literárnu tvorbu prvej polovice 20 . storočia cez vedomie dynamiky vývoja literatúry a jej pluralitného charakteru, čím sa 
priestoru a priestorových rekvizít tu vystupujú ako dôležité významotvorné činitele, ktorých porozumenie predpokladá prekročenie hraníc textu cez prostriedky komplexného literárnovedného výskumu, následne si však vyžaduje spätný návrat $\mathrm{k}$ textu. V tomto prípade - v zmysle metodologickej inštrukcie M. Bátorovej ${ }^{4}$ - nám text slúži nielen ako východisko interpretačných analýz, ale v závere zároveň aj ako ich verifikátor $(2016,2018 \mathrm{a})$. Výber textov je preto cielený a dostatočne reprezentatívny na to, aby vypovedal o charaktere špecifických poetík slovenskej a českej medzivojnovej moderny. K uvedenému cielu nevyhnutne prislúcha ambícia vytvorit typologický reliéf súvislostí, ktoré jestvujú na základe procesu vzájomného prepojenia kultúr a ich literatúr v užšom stredoeurópskom kontexte. ${ }^{5}$

Ak osudy protagonistov v románoch Di̊m o tisíci patrech (1929) od Jana Weissa a Pisár Gráč (1940) od J. C. Hronského vnímame ako výpovede-artefakty, úzky epický priestor, v ktorom sa tieto osudy odohrávajú, má potom v zmysle pars pro toto zastupovat osudy ludí v medzivojnovom svete $\mathrm{s}$ črtou neukotvenosti, existenčnej nestability. ${ }^{6}$ Dané ponímanie kompozičnej kategórie priestoru v próze literárnej moderny zároveň vedie $\mathrm{k}$ rekonštrukcii určitých mimotextových súradníc. Komplexný literárnovedný prístup ku konkrétnym literárnym textom je cez ich textovú analýzu nevyhnutne doplnený o sociologický aspekt, kedže textové jednotky, akými sú priestor a jeho vlastné rekvizity, v rôznej miere korešpondujú so svetom nachádzajúcim sa mimo nich. ${ }^{7} \mathrm{~V}$ individuálnom spôsobe, akým spisovatelia stvárňujú epický priestor, tak možno hladat' metaforu/metonymiu vypovedajúcu o zložitosti, prípadne špecifickosti istého dejinného i životného výseku, v ktorom sa ten-ktorý spisovatel nachádza, a teda ku ktorému sa kontextovo vztahuje. ${ }^{8}$ Potom aj cez identifikáciu poetík vybraných literárnych diel možno zaznamenat charakter odchádzajúceho sveta prvej svetovej vojny a chaosu, ktorý vo svete spôsobila. Umenie takýmto spôsobom komunikuje širšie kontexty svojho vzniku. To, čo stredoeurópskych autorov typologicky spája, je okrem spôsobu, akým stvárňujú svojich protagonistov, ${ }^{9}$ aj postup konštruovania kategórie priestoru.

do istej miery popiera striktná periodizácia (1. zväzok [2010] reflektuje literárnu tvorbu v rozpätí rokov 1905 - 1923, 2. zväzok [2014]: 1924 - 1934, 3. zväzok [2017]: 1935 - 1947).

4 Vychádzame z metodológie A - T - Č a ich kontexty M. Bátorovej, ktorá je ako metodologický model rozpracovaná najmä v monografii Jozef Cíger Hronský a moderna (2000).

5 Týmto nadväzujeme na konkretizáciu moderny F. Wollmanom na stredoeurópsku modernu ako špecifickú literárnu a kultúrnu štruktúru (1988). Aj napriek tomu, že mnohorozmerné spojenie, akým je literárna moderna, nemožno zredukovat do jasne ohraničenej definície, hladanie „typologických súvislostí (Ďurišin 1985), ktoré jednotlivé stredoeurópske literatúry spájajú, napokon prispievajú k vymedzeniu jej špecifickej symptomatiky.

6 J. L. Lotman hovorí o dvojakej povahe umeleckého modelu - tým, že odzrkadlujúc jednotlivú udalost', odzrkadluje zároveň aj celý obraz sveta, rozprávanie o tragickom osude hrdinky rozpráva o tragickosti sveta ako celku (Lotman 1990, 248).

7 „História, filozofia, sociológia sú sprievodné vedné disciplíny, ktoré pomáhajú vidiet literárny text nielen ako separovaný artefakt, ale pomáhajú ho rekonštruovat's ohl’adom na čas jeho vzniku (literárnohistoricky) i nadčasovo, t. j. určit jeho univerzálny prínos či „zmysel“ v danom „diskurze“svojho času“ (Bátorová 2011b, 58). K. Benyovszky v súvislosti s interpretáciou teoretickej koncepcie M. Tokára o významotvornom princípe ikonických ilustrácií ako zmyslovej podobnosti „výrazu s realitou“ deklaruje, že „spôsob obrazno-metaforickej reprezentácie sa nevztahuje iba na text, resp. fiktívny svet literárneho diela, ale v niektorých prípadoch smeruje aj k „skutočnosti“ mimo textu“ (Benyovszky 2018, 97).

8 O výpovednej hodnote umenia hovorí aj P. Bourdieu, podla ktorého „literární dílo někdy může říci více, a to i o společenském světe, než řada spisů s vědeckými nároky [...]. Ovšem literatura to říká pouze nepř́mo, jako by to neříkala doopravdy. Vyjevení skutečnosti je omezeno tím, že si spisovatel ponechává jakýsi dohled nad možným průnikem podvědomě vytěsňovaných sdělení. Ztvárnění slouží jako všeobecný eufemismus, realita je literárně odreálněna a neutralizována [...]“ (Bourdieu 2010, 57).

9 M. Bátorová uvedené paralely (napr. W. Gombrowicz, S. Márai a J. C. Hronský) odôvodňuje pôsobením 
Kedže obaja autori boli priamymi účastníkmi prvej svetovej vojny, ${ }^{10}$ ich románový priestor spolu s priestorovými rekvizitami vnímame na jednej strane ako výraz bezprostrednej konfrontácie s vojnovým stavom, ale zároveň aj ako produkt psychológie, filozofie či sociológie prvej polovice 20. storočia a medzinárodných kontaktov jednotlivých národných literatúr. Cez pôsobenie vlastnej skúsenosti ${ }^{11}$ vzniká v próze medzivojnovej literárnej moderny jej autentický alegorický odkaz zasadený do určitého (nie náhodného) epického priestoru, ktorý M. Bátorová vymedzuje ako prechodnú stanicu, ${ }^{12}$ na ktorej treba nejako prežit' $(2000,29)$. Súradnice prechodného priestoru, do ktorého autori situujú svojich protagonistov, sú totiž pohyblivé. Podla H. G. Gadamera je práve pohyb základným stavebným prvkom hry, pričom zakaždým ide o pohyb sem a tam bez vytýčeného ciela. Hra ako pohyb totiž nesleduje žiadny ciel', v ktorom by našla svoje ukončenie, práve naopak - obnovuje sa v neustálom opakovaní (Gadamer 2010, 105). Uvedenú tézu o absencii ciela pohybu možno aplikovat’ aj do oblasti umeleckej tvorby mimetická reprezentácia presahuje text tým, že vypovedá v kontexte medzivojnovej moderny o rôznych psychických deformáciách (taktiež aj fyzických, ktoré napokon vyvolávajú deformácie psychické), teda o určitej vnútornej realite blúdiaceho človeka bez dosiahnutia ciela jeho pohybu. Takýmto spôsobom vzájomné prepojenie pohybu a priestoru identifikujeme v literárnej moderne ako výraz hry vlastného nevedomia, kedže práve na tomto mieste má osobitnú významotvornú funkciu najmä priestor vnútorný. Weiss situuje hlavného protagonistu Petra Broka do jedného (nevediac ktorého) z poschodí tmavého domu, plného úzkych chodieb bez dverí či

podobných osudov podmienených politicko-spoločenskými pohybmi v Európe v prvej polovici 20. storočia (Bátorová 2004, 140).

10 Zatial' čo autentické vojnové skúsenosti Jozefa Cígera Hronského vychádzali z jeho účasti na talianskom fronte (napr. bitka na Piave), Jan Weiss zase bojoval na ruskom fronte, počas bitky o Tarnopol v roku 1916 bol zajatý a následne väznený v zajateckých táboroch. No okrem vojnovej skúsenosti ako jedného zo životných výsekov podielajúcich sa na profilovaní charakteru tvorby jestvujú aj iné, podobne (možno i viac) intenzívne zážitky. K mimoliterárnym vplyvom na samotný proces tvorby sa Jan Weiss vyjadril nasledovne: „Myslím, že u každého člověka, nejen u autora, je v životě období, kdy žije jaksi nejintenzivněji, období, které ho nejsilněji poznamenává pro všechna př́ští léta. U mne to kupodivu nebyla válka - první světová válka, kterou jsem prošel jako voják a zajatec - ač i ta zanechala v mé práci silné stopy - ale mé dětství v rodném kraji, svět pohádek a dobrých i nedobrých, ale vždy svérázných lidiček" (Weiss 1966, 10). Na rozdiel od archívu súkromnej korešpondencie J. Weissa, ktorú v zmysle Ďurišinovej komparatistickej teórie zaradujeme ku genetickým (kontaktovým) vztahom, korešpondencia, ktorú počas života viedol J. C. Hronský, zachovaná nebola, a tak pri analýze literárneho textu vychádzame, okrem iného, z reflexie jednotlivých kompozičných kategórií románu, ktoré zaradujeme k typologickým súvislostiam, avšak za tažiskového rešpektovania autenticity autorských literárnych výpovedí. „Nie je to však len autenticita vonkajších kontúr autorskej skutočnosti, ktorá by sa prejavovala tým, že by interpreta provokovala priamymi dátami zo života uvedenými v texte. Pod autenticitou [...] diel rozumieme okrem faktov aj výpovednú hodnotu textu a „atmosféru“ textu: rozptýlenost’ autorského subjektu v diele [...]“ (Bátorová 2011a, 46).

11 Ak za literárnym textom vidíme autora ako jedného z členov komunikačnej triády autor - text - čitatel' so svojimi vlastnými kontextami, reflexia životných výsekov Jana Weissa a Jozefa Cígera Hronského, ako aj ich potenciálny vplyv na individuálnu umeleckú tvorbu, sú pre textovú analýzu napokon nevyhnutné.

12 Kontext doby, v ktorej vznikajú predmetné romány, odkazuje na vnímanie stredoeurópskeho priestoru (a v rámci neho i Československa) v zmysle „prechodnej miestnosti v pomerne širokom, priestrannom európskom dome. Je to prechodné územie, lebo sa ním prechádza. Od Západu na Východ a od Východu na Západ. Je to územie zakázanej neutrality“ (Koška 1998, 42). V nadväznosti na celospoločenskú situáciu dvadsiateho storočia, ktoré sa do svetových dejín zapísalo predovšetkým ako obdobie dvoch svetových vojen, možno uvedený alegorický obraz strednej Európy - prechodného priestoru - adekvátne obhájit na základe špecifík kompozičnej stavby vybraných literárnych diel. 
okien. Ak tento priestor vnímame ako výraz intímnej „topografie“ ludského bytia, potom sú aj priestorové kulisy predovšetkým kulisami mysle a duševných stavov protagonistov.

„[...] ve stěně se objevil otvor, vedoucí do tmy. Petr Brok se tiše protáhl. Uzavřel za sebou poklop. Ocitl se v černé, nízké chodbičce. [...] Pomalu sunul se kupředu. Ale když ušel několik krokì, uviděl v hlubině temna tenkou, zářivou nitku, visící ze tmy do tmy. Když k ní došel, shledal, že je to úzká štěrbina v prkenném pažení, kterým byla chodbička ukončena. Přibližil oko a štěrbina se rozestoupila v šedivou komůrku bez oken. - Stůl, džbán, židle, žárovka, železné li̊žko" (Weiss 1990, 16 - 17; zvýraznila Z. CH.).

V románe Di̊m o tisíci patrech sa protagonista pohybuje v priestore domu primárne po vertikále. ${ }^{13}$ No okrem základnej vertikálnej osi modernistického pohybu zdola-nahor/zhora-nadol B. Čahojová-Bernátová hovorí o špecifickom významovom rámci cyklickej štruktúry modernistického pohybu, ktorý identifikuje aj v oblasti výtvarného umenia - na pozadí Munchovej malby Výkrik (1893). Priestorové parametre sa tu stáčajú do kruhov ako víry stahujúce objekt smerom nadol, nižšie, pričom kruhový tvar symbolizuje paralelne začiatok i koniec. V danom koncepte tak kruhy kopírujú špirálu bezvýchodiskovosti plynúcej z úzkosti (Čahojová-Bernátová 2009, 10). O významovom paralelizme cyklickosti s vertikálou modernistického pohybu svedčí opakovaný prechod hlavného protagonistu Petra Broka z nižších poschodí na vyššie a naopak, ktorý je bezvýchodiskovým stúpaním a klesaním v nekonečnom priestore poschodí bez konca. ${ }^{14}$ Hovoríme o analogickej trajektórii asociácií vztahujúcich sa k priestoru a pohybu v ňom, ktoré $\mathrm{v}$ oboch prípadoch, teda $\mathrm{v}$ literárnom texte, ale aj v cielene vizuálnom texte, akým je obraz, vyvolávajú podobné významotvorné recepčné procesy, kedže ich interpretujeme na základe rešpektovania vlastných kontextov ich vzniku. V tomto ponímaní konkrétne vizuálne stvárnenie priestoru, v ktorom sa subjekt pohybuje, prípadne je ním obklopený, považujeme za významovú súčast̉ textu ako artefaktu do istej miery vypovedajúcom o niečom, čo sa nachádza mimo neho.

"-Kde to jsem?

Člověk se vymrštil. - Doli̊, či nahoru?

- Vzhưru!

Tři čtyři stupně vešly se do úhlu jeho nohou. Pustá plošina odpočívala mezi dvěma patry, bez oken, bez dveří. A opět schodiště pokryté rudým kobercem. Pak zase patro, slepé, hluché, s bílou lampou u stropu. - Rudý koberec! - Vzhưru! - Šarlatové lano jako had nekonečně dlouhý visí po pravici a po levé stoupají kužely.

Kdy tomu bude již konec? Kde jsou dveře? Člověk ubíhá vzhưru. Hlava se mu motá, purpurová kaskáda koberce pálí ho do mozku.

13 Uvedená priestorová metafora šifrovaná do pohybu protagonistu spočíva v identifikovaní tela umiestneného alebo pohybujúceho sa v priestore. Týmto nadväzujeme na teoretický koncept priestorových metafor G. Lakoffa, M. Johnsona a M. Turnera, podla ktorého opozície, ako napr. hore/dolu (najbohatší zdroj metafor a zároveň základná významová opozícia moderny), vpredu/vzadu (metafory času - prelínanie minulosti a budúcnosti), organizujú priestor prostredníctvom používania tela ako orientačného bodu (Ryanová 2010, 41). Napokon, jedna z hlavných téz všeobecnej teórie relativity ako mimoriadneho impulzu estetiky moderny nového storočia vypovedá o tom, že vlastnosti priestoru sú určované telesami, ktoré sa v ňom nachádzajú (Vojvodík 2010, 58). Podobne v tomto prípade charakter priestoru určuje vnútorný stav protagonistu, kedže ide o priestor snový, psychický.

${ }_{14}$ Aj napriek tomu, že názov románu limituje uvedený priestor tisícim poschodím, jeden z protagonistov (slepec) hovorí Brokovi o dome ako nikde nekončiacom priestore, kedže dalšie poschodia sa neustále stavajú. 


\section{Najednou se zastavil. - Snad... snad by bylo lépe utíkat dolů! - Nazpět! - Ne! To již je poz- dě! Př́liš vysoko jsem vystoupil. - Vzhůru!“"(Weiss 1990, 8; zvýraznila Z. CH.)}

Pohyb sem a tam zjavne patrí $\mathrm{k}$ hre vlastného nevedomia ( $\mathrm{v}$ tomto prípade snového sveta) natolko bytostne, že v istom konečnom zmysle nemožno „hrat' iba sám pre seba“. Aby sme mohli hovorit” o hre, nemusí sa jej síce skutočne zúčastnit niekto iný, avšak vždy tam musí byt niečo iné, s čím hrajúci hrá a čo na hráčov tah samo odpovedá protitahom. Ludské hranie sa proti všeobecným určeniam hry vyznačuje tým, že človek hrá niečo (Gadamer 2010, 106, 108). Podobne aj protagonisti diel literárnej moderny často oscilujú na osi subjekt (ja) - objekt (ono), pričom tento pól môžeme vnímat’ $\mathrm{v}$ intenciách hry ako uvedené niečo. Oscilácia na danej osi spočíva v postupnom procese premeny zo subjektu na objekt a následne jeho stotožnenie s novou identitou subjektu, pričom k osobnostnej premene zväčša dochádza pomocou pôsobenia priestorovej rekvizity. ${ }^{15}$ Kompozičnou stratégiou, ktorou je zrejme zámerná volba názvov kapitol, J. Weiss naznačuje, aké priestorové rekvizity budú pre danú sujetovú čast’ významovo nosné. Zatial čo názvom prvej kapitoly autor konštruuje obraz úvodnej sujetovej „scény“ sna cez schodisko a červený koberec, priestorové rekvizity tvoriace súčast” názvu tretej i šiestej kapitoly (zrkadlo, dvere, koniec chodby) nepriamo predznamenávajú vyššie uvedenú osobnostnú transformáciu, teda proces novej sebaidentifikácie protagonistu, ktorá sa má uskutočnit cez pohlad do zrkadla ${ }^{16}$ umiestneného na konci chodby. Takéto priestorové vymedzenie možno vnímat v zmysle Ryanovej definície priestorového rámca ako súčasti naratívneho priestoru, ktorý mení obraz konania postavy v súčinnosti s jej pohybom naprieč priestorovým rámcom (Ryanová 2010,39) - v tomto prípade ostrou, zretelnou hranicou, akou je koniec chodby so železnou klietkou.

„»Na konci chodby, "ř rekl stařec, » visí železná klec. [...] Za touto klecí je výklenek. Visí tam na stěně broušená deska, hladká a studená jako had. - Nevím, je-li to zrcadlo. - Ale když si pred ni stoupnu, zdá se mi, že se na mne dívá moje slepota... Nevím. - Snad je to jen sklo!« $[\ldots]$

15 Iným príkladom oscilácie medzi dvomi pólmi je zmena naratívnej situácie v novele Pach (1943) od Dominika Tatarku, ktorá sa uskutočňuje pod vplyvom jeho kontaktu s konkrétnymi predmetmi priestorovými rekvizitami. „Brúsi si dýčku ostrou skalkou. [...] Dýčku si brúsi ostrou skalkou. [...] Ostrou skalkou si brúsi dýčku chlap. [...] Dýčku si ja brúsim ostrou skalkou“" (Tatarka 1943, 391, 392). Zmenu gramatickej osoby vnímame ako opačný prechod od on $\mathrm{k} \mathrm{ja}$, teda ide o vyjadrenie postoja $\mathrm{k}$ minulej udalosti na základe neprítomnosti/prítomnosti vlastného vedomia. Zatial čo v prvotnom opakovaní brúsenia dýčky ako „zaklínadla“ sa protagonista nepovažuje za činitela deja, rovnako ani snovú predstavu nevníma ako skutočnost', v závere sa s činitelom deja protagonista stotožňuje. F. K. Stanzel charakterizuje striedanie gramatických osôb ako pokus o dištanciu hovoriaceho od prežívajúceho (Stanzel 1988, 130), čo považujeme za jednoznačný symptóm vnútorného zmätku protagonistu oscilujúceho v čase (prítomnost vs. minulost'), ale i v priestorových súradniciach sna a reality. Dušan ostrí svoju vražednú zbraň skalkou, v ktorej je podla $M$. Bátorovej zašifrovaná tvrdost’ neprekonatelnej skutočnosti v sebe, ide o ostrenie vlastnými spomienkami (Bátorová 1992, 134).

16 O zrkadle ako jednom $\mathrm{z}$ dominantných motívov Weissovej prozaickej tvorby vypovedá aj názov zbierky šiestich poviedok Zrcadlo, které se opožduje (1927). V poviedke s rovnomenným názvom autor prostredníctvom zrkadla narušuje časovú lineárnost', a to tým, že „[$[v]$ šechny věci, které se na tebe dívaly $z$ této hladiny, lišily se od své skutečnosti jistou časovou diferencí. Za nespočetných dnů a nocí stárly stěny proti zrcadlu, a jejich odraz běžel za nimi, vzdálen o několik kroků do minulosti. - Nejpodivuhodnějši ze všeho však bylo, že toto časové rozpètí mezi originálem a reflexí často velmi rozmarně a neočekávaně se mènilo, prodlužovalo se (až na čtyř minuty) nebo se krátilo, až se téměr dotýkalo současnosti. Stalo se někdy (tenkrát zrcadlo viselo ještě v Starém divadle), že osoba přistoupivší k němu svého obrazu vủbec se nedočkala" (Weiss 1964, 101). 
Brok predhonil starce, sobálkou v ruce skočil ke stèně a pohlédl na sebe.

Výkřik překvapení se mu vydral z úst!

Vztyčil se proti zrcadlu. Zamával rukama. Vyskočil. - Dával všelijaká znamení, že tu je, že tu

stojí člověk před zrcadlem - nadarmo - zrcadlo ho nevidělo - zrcadlo ho nevzalo na vědo-

mí - Zrcadlo bylo prázdné!“ (Weiss 1990, 28 - 29; zvýraznila Z. CH.)

Popri prekročení zretelne vymedzeného priestorového rámca ${ }^{17}$ sa proces novej sebaidentifikácie završuje pohladom do zrkadla. J. M. E. Lacan postuluje tézu o obraze zrkadla ako klúčového činitela pri formovaní identity, takže proces sebauvedomovania sa podla tejto tézy má uskutočňovat prostredníctvom rozpoznania vlastného obrazu v zrkadle (Démuth 2008, 2). Peter Brok však vlastný obraz v zrkadle nevidí, no táto neviditelnost’ sa stáva súčastou jeho špecifickej snovej identity v priestore Mullerdómu na rozdiel od paralelnej identity neznámeho vojaka-zajatca nakazeného týfusom v uzavretom naratíve - v zajateckom priestore. Ide tak o dvojaký priestor, ktorý je založený na prvotnej protikladnosti dvoch svetov (snového a „reálneho“), avšak špecifická „realita" fyzickej trýzne vojaka sa tu do rôznej miery podiel’a na charaktere snovej psychickej trýzne. ${ }^{18}$ Spojivom paralelných svetov, medzi ktorými protagonista $\mathrm{v}$ dvoch identitách osciluje, sa stáva lampa ako významová priestorová rekvizita umiestnená na strope každého poschodia Mullertonu („oko“ Ohisvera Mullera) a lampa svietiaca nad lôžkom zajatca. Z uvedeného dôvodu nejde o priestor kontrastný, snový svet je iba fiktívnou alternatívou, ktorá aj napriek určitej logickej nemožnosti demonštruje vnútorný svet indivídua.

Interpretáciou priestoru, s ním súvisiaceho pohybu, ako aj priestorových rekvizít, teda kategórií, ktorými Ján Weiss prevracia perspektívu umelca smerom dovnútra, sme nadviazali na interakciu literatúry s výtvarným umením. ${ }^{19}$ Podobne aj priestor v románe Pisár Gráč je v určitých pasážach skonštruovaný cez maliarsku techniku, podla ktorej sa svet nálad a emócií protagonistov šifruje do farebného záznamu. ${ }^{20}$ Ten je potom akousi vizuálnou nadstavbou jazyka. J. M. Lotman hovorí o možnosti modelovania pojmov tzv. "farebného priestoru“ (Lotman 1990, 250), ktoré síce

17 V tejto súvislosti možno uviest taktiež funkčnost̉ priestorových rekvizít, akými sú dvere či prah, ktoré taktiež fungujú ako hraničné priestorové rámce pre rozpoznanie novej/inej identity.

18 Fyzická trýzeň poznačila J. Weissa počas jeho väznenia v zajateckom tábore Trockoje, kde sa nakazil týfusom, pričom dôsledky tažkých týfusových horúčok sa podla zachovaných spisovatelových záznamov (napr. výpovede o brutalite $\mathrm{v}$ zajateckých táboroch publikované $\mathrm{v}$ Literárních novinách) prejavili $\mathrm{v}$ zhoršenej pamäti a $\mathrm{v}$ poškodenom vnímaní času a priestoru. No tento negatívny zážitok bol umocnený dalšou fyzickou trýzňou - amputáciou deviatich prstov na nohách kvôli rozsiahlym omrzlinám (Nájemník).

19 J. Weiss napokon sám inklinoval k výtvarnému umeniu, o čom svedčí jeho rozsiahla zbierka obrazov, predovšetkým českého maliara Jana Zrzavého (1890 - 1977) - meno, ktoré vdaka osobitému štýlu tvorby možno právom zaradit $\mathrm{k}$ tvorcom moderného umenia vypovedajúcom o rôznych duševných stavoch, o čom hovorí aj on sám: „Mé umění je predvedením oněch stavů duše kotvících v samé tmě podvědomi" (Frajerová 2018). No nielen výtvarné texty môžeme chápat a zároveň aj interpretovat ako ohraničené objekty, ktoré do rôznej miery odrážajú istý vnútorný stav. Hladanie určitých významových paralel medzi literárnym textom/verbálnym umením a výtvarným textom/vizuálnym umením je relevantné, kedže literárny text „nemá iba verbálny charakter, jeho graficky fixovaná podoba má i vizuálne, t. j. zrakovo vnímatel'né kvality. Vdaka nim ho možno pokladat (aj) za obraz" (Benyovszky 2018, 105).

20 Spôsob konštruovania priestorovej atmosféry, ktorý predstavuje samostatnú dimenziu v estetickej kvalite Hronského literárnych textov, priamo vypovedá o autorovom bytostnom vztahu k maliarskemu umeniu. Sám Hronský si väzbu s maliarstvom, prejavujúcou sa ako schopnost vytvorit vizuálnu podobu verbálneho umenia, uvedomoval a aj napriek tomu, že výtvarné štúdiá neabsolvoval, maliarsky talent napokon aj tak preniesol do inej umeleckej sféry - literárnej tvorby. „Chcel som byt maliarom, mal som už pozháňané aj akési štipendiá, ale otec - robotník mal na starosti ešte školovanie šest mojich súrodencov, velmi málo 
samy o sebe nemajú priestorovú povahu, ale dotvárajú špecifickost’ priestorovej imaginácie, a tak ich môžeme oprávnene zaradit' ku komponentom priestorových rekvizít. O využití podobnej techniky vypovedá románový úryvok o duševnom stave mladého vojaka - Jožka Gráča, ktorý hladá únik pred vojnovým chaosom v prírodnej scenérii.

„Pchá hlavu do akejsi jelšiny a hladá chládok pri potoku. Sadá na velký zvariak, ktorý vyvalila sem voda, vyumývala, zaokrúhlila, oriadila, a hlúpo sa díva do vody. [...] Prižmuruje lavé oko a z blúzy vytahuje malú akvarelovú kazetku i náčrtník. [...] Tak mu tečú myšlienky ako voda v potoku: od hocikial' a hocikade. - Malovat' idem. Musím. Kamene, velké kamene s trochou štebotavej vody sú ako utešené javisko, kde sa všeličo odohralo a kde sa ešte všeličo odohrá. Pukliny na kameňoch sú ako velké a tažké rany a divý chmel ako láskavý, krásny obväz. Ozrutné lopúchové listy sú tu nie ledačina, ale najkrajšia kytica, zeleň je ako hodvábne dievčenské dlane, po ktorých sa prechádza slnce. Na kameňoch sú fialové tiene a živé okrové slnečné škvrny, zlatá siet', vel'ká zlatá pavučina, ktorá sa zakaždým zachveje, ked'vetrík pohne listy. Kmene jelšiny sú celkom ultramarínové, a to iste len pre túto chvílu sa tak vyzdobili, lebo ináč nepeknú majú kôru. Voda je pod kameňmi celkom smaragdová. Tam zrazu stíchla, ako by sa bola nalakala zlatého vetra a hustej, drahokamovej farby, ktorú tu naozaj dostala. Hen je hned' lúka, taká cinóbrová, od makovíc, a potom nebo, nebo, belasé nebo. Vôbec celý pohlad odtialto je ako pohlad do neba, skutočného a opravdivého neba!“ (Hronský 1940, 75 - 76; zvýraznila Z. CH.)

Akcent na významový rámec farieb evokuje prácu so základnými stavebnými prvkami impresionistických, ale aj expresionistických malieb. ${ }^{21}$ No ako uvádza S. Little, zatial čo impresionisti pracovali primárne so schopnostou vnímat svetlo, farbu a pohyb, ktoré majú byt výrazmi stavu okamžitej chvíle, expresionistická farebná škála už nie je iba výsledkom momentálnej impresie, ale predstavuje výpoved’o autentických emocionálnych pohyboch v psychike postáv (Little 2012, 104). Hronského farebný záznam je však kombináciou a vzájomným prelínaním oboch postupov, kedže priestorová scéna tvorená svetlom, farbami a pohybom (teda špecifickými rekvizitami priestoru) tu síce funguje ako výraz okamžitej chvíle, avšak spôsob jej stvárnenia je zároveň autentickou výpoved’ou o psychickom rozpoložení protagonistu majúcom univerzálnejšiu platnost', ak zoberieme do úvahy významový paralelizmus dvojíc vojak-kameň, pukliny-rany, chmel-obväz.

Hronský tak raz narába s priestorom ako s kulisou, inokedy je priestor pôdou nálad a emócií protagonistov, projekciou ich duchovno-duševných obsahov, ktorá prechádza až do sféry abstrakcie, alebo autor vníma vonkajší svet ako symbolickú rekvizitu sveta (Bátorová 2011a, 81 - 82). Epickým priestorom, cez ktorý dochádza k najvýraznejšiemu prestupu do sféry abstrakcie, je v románe Pisár Gráč cirkus. Groteskná podoba cirkusu J. C. Hronského zjavne zastupuje dvojakú tvár 20. storočia, „tvár varieté, cirkusu, ožiarenú reflektormi a tú istú tvár - dennú, sivú, ktorá demaskuje kamufláže verejných cirkusových predstavení" (ibid., 110). Tvarové znaky cirkusového priestoru potom funkčne vypovedajú o pozícii indivídua v absurdnom svete, kde je človek iba hercom, klaunom. V nadväznosti na vymedzenie grotesky ${ }^{22} \mathrm{M}$. Pokrivčákovou vnímame daný

prostriedkov a azda ešte menej dôvery, že narábanie štetcom je naozaj seriózne zamestnanie“ (Hronský 2008, 519).

21 Vzájomné prelínanie tvorivých postupov jednotlivých umeleckých smerov, štýlov či hnutí, na mnohých miestach dokonca ich antagonizmus, dotvárajú špecifický charakter vybraných diel slovenskej, ale i českej medzivojnovej prózy a jednotlivých autorských poetík.

22 Kedže pri identifikácii symptómov moderny postulujeme tézu o zmenenom vztahu medzi človekom a Bohom (nadväzujeme na vymedzenie novovekej moderny W. Welschom [viac pozri Welsch 1994] popri 
epický priestor ako zmenšenú alegorickú konštrukciu sveta na báze imaginatívneho dotvárania známej reality (Pokrivčáková 2002, 7). Napokon, groteska spolu s absurditou predstavujú časti základov moderny ako takej, kedže ich počiatočné umelecké prejavy súvisia so spochybnením tézy, „že ludská spoločnost’ a celok sveta nie sú výrazom racionálne organizovaného a dobrého (správneho) usporiadania, ale skôr ne-poriadku a nekontrolovatelného chaosu [...] a súvisia so stratou náboženskej viery“ (Mitka 2017, 82), resp. s jej spochybnením, pričom uvedený životný pocit sa prehĺbil práve po vojnovej skúsenosti.

„Vždy som mal vrelý vztah $k$ cirkusu! Myslím - aj k cirkusáctvu. [...] Pravda, ked' som bol chlapcom, vtedy som ešte nevedel, že celý svet je cirkus, a myslel som si, že cirkus je iba tá velká okrúhla plachta, okrúhly šiator na kolíkoch a cirkusanti v pásikovaných košeliach. Vtedy som iba takýto cirkus obdivoval. [...] Ja viem, čo je cirkus! Mňa reflektory neoslepili a ja som videl chýrneho Johna Billa i vtedy, ked’nemal na sebe hodvábnu košelu a lakové topánky a hodvábny a lakový úsmev, ale iba žltú, nevrlú tvár a ovisnutú gambu. Ja som videl cirkus cez deň, ked'bol ošúchaný, ked'bol strašne prázdny. [...] Cirkus bol celkom, celkom prázdny. Tmavý, chladný, záhadný a taký strašidlove velký [...]“" (Hronský 1940, 86 - 87; zvýraznila Z. CH.).

V momente demaskovania skutočnosti za detskou ilúziou o kráse a zázračnosti zahalenej do cirkusového šapitó je protagonista sám, a to v priestore zvyčajne preplnenom, rušnom. Prežívanie situácií existenčnej povahy vo vyprázdnených priestoroch odkazuje na opustenost’ postáv, ich izoláciu od okolitého sveta. ${ }^{23}$ Atribút osamotenosti je umocnený aj tým, že protagonistom neprislúcha stály domov, ku ktorému by boli emocionálne viazaní, zväčša bývajú v prenajatých bytoch či hotelových izbách. Topoi domova sa však u Hronského neviaže výlučne k materiálnemu vlastníctvu - domu ako budovy. Slovami M. Bátorovej, skutočný domov totiž predstavuje aj iný človek a práve ten býva často „miestom“, kde sa autorovi hrdinovia na čas usadia (Bátorová 2000, 30). Potreba pevného, stabilného miesta sa teda prelína od symboliky domu k symbolike ženy - blízkej osoby. Napokon, ako poukazuje H. Biedermann, už Freudova psychológia, ktorá bola pre toto

druhej z možných koncepcií moderny viažucej sa k viedenskej moderne), potom aj počiatky groteskného výrazu moderny možno identifikovat už ovela skôr, a to vo výtvarnom umení 18. storočia spojenom s významnými menami, akými je v Španielsku F. Goya - výsmech súdobej spoločnosti či karikovanie božskej autority v súbore grafických listov s názvom Rozmary [Los Caprichos]; „[j] eho hlas byl lidským i božským hlasem věku [...], jako by se sám stvořitel vysmival a rouhal člověkovi, s nímž je préece spjat tou nejrodnějši účasti“ (Čapek 2018, 104), v Anglicku W. Blake - popri malbách má dôležité miesto jeho básnická tvorba, v ktorej Blake karikuje Boha do podoby ludskej krutosti, napr. v básni „Obraz boži“: „Ukrutnost lidské srdce má / a žárlivost má lidskou tvár. / Hrůza má lidskou podobu / a lidský šat má tajnůstkár. / Lidský šat lité železo, / lidský zjev v ohni ukován, / lidská tvár̆ rozpálená pec / a lidské srdce chtivý chřtán“" (Blake 2018, 41), alebo neskôr v 19. storočí J. Ensor - emblematickou črtou Ensorových malieb je motív masky ako grotesknej podoby človeka, spoločnosti, pričom uvedený motív má pôvod v množstve rituálov, kde prostredníctvom nasadenia masky človek môže vstúpit do komunikácie, resp. konfrontácie s bohmi.

${ }^{23}$ Iným príkladom pre uplatnenie prázdneho priestoru ako jedného zo symptómov literárnej moderny je epický priestor protivojnovej novely Pach (1943) od Dominika Tatarku. Protagonisti-mladomanželia cielene odchádzajú do hotela, ktorý má byt únikom pred verejnostou, ich intímnym priestorom. No aj napriek pôvodnému zámeru sa volbou hotelovej izby všetky súkromné chvíle menia na verejné - hotel je totiž vo svojej podstate budovou verejnou. „Vrátnik vyzeral za nimi zdola. Mňam, mňam, novomanželia. Tí sa vám budú oblizovat. Podívajte sa, Klárka, tí sa budú oblizovat" (Tatarka 1943, 388). Izolovanie protagonistov do ohraničeného priestoru hotelovej izby v istom zmysle predznamenáva stavy ich hlbokej osamotenosti. Aj napriek prítomnosti nábytku či iných hotelových rekvizít ide totiž o prázdny priestor, v ktorom sa proces hladania vlastnej identity človeka zasiahnutého vojnovou skúsenostou opät nezavršuje. 
obdobie skutočným inšpiračným zdrojom, priradila symbolický význam domu práve žene/matke/ rodičke (Biedermann 1992, 61).

Kedže dom vnímame ako východiskový priestorový bod pre budovanie a následne i zachovanie stability či vlastnej identity, jeho absenciu alebo významovú deformáciu v próze literárnej moderny možno považovat za další z jej identifikačných symptómov. Aj ked' názov románu Jána Weissa naznačuje, že hlavným dejiskom sujetu bude dom a s ním spojený pocit pozitívnej ukotvenosti v priestore, autor túto priestorovú ohraničenost' zároveň bližšie špecifikuje tisícimi poschodiami, čím predznamenáva oxymorické spojenie domu-stability a pohybu v labyrinte schodiska-nestability. Pôvodne uzavretý naratív je takto zmenený na otvorený a odcudzujúci priestor (labyrint putovania).

\begin{abstract}
„Jako by život začínal tím probuzením na schodišti. - A chceš-li si vzpomenout, probudís divokou bolest, která kdesi uprostřed mozku sebou cuká jako podebraný vřed. [...] Di̊m o tisíci patrech!... Ale to přece není di̊m! To je obrovské město pod jednou střechou! A já mám proniknout tímto labyrintem?" (Weiss 1990, 14, 15; zvýraznila Z. CH.)
\end{abstract}

Vo vymedzení symptomatiky literárnej moderny uvádzame za tažiskový a zároveň aj východiskový bod perspektívu introspekcie. ${ }^{24}$ Koncentráciou pozornosti na individualitu, akou je človek so svojím autentickým vnútorným svetom, moderna anticipuje objavenie štvrtej dimenzie, ktorou je podla B. Čahojovej-Bernátovej vnútorný priestor a čas ludskej mysle (Čahojová-Bernátová 2009, 10). V dôsledku tohto naratívneho obratu sa mení aj naše ponímanie epickej kategórie priestoru vo vybraných literárnych textoch. Popri čase ${ }^{25}$ vystupuje priestor ako jedna z určujúcich kompozičných kategórií s vlastným významovým rámcom, často sa javiacim ako reliéf psychiky protagonistov, výraz introspekcie. $\mathrm{V}$ tejto súvislosti hovoríme o istej kauzálnosti medzi vnútorným (psychickým) a vonkajším (priestorovým), čím nadväzujeme na Hoffmannovu koncepciu priestoru ako naratívnej kategórie. Gerhard Hoffmann totiž rozlišuje tri priestorové modely (náladový priestor, priestor konania a priestor nazerania), pričom práve náladový priestor (gestimmter Raum), ktorý je zároveň aj priestorom konania a vnútorného nazerania, možno považovat’ svojimi špecifikami za klúčový pri identifikácii diel literárnej moderny, kde miesta a predmety (nazvané rekvizitami) majú symbolický význam. Predmety a postavy tu obklopuje istá atmosféra - podobne ako je tomu pri vymedzení náladového priestoru G. Hoffmannom (Dvorský 2017, 92).

24 Pojem introspekcie volíme zámerne, pretože ide o jednu z najstarších metód skúmania subjektívnej skúsenosti, ktorá je založená na vnútornom pozorovaní a vnímaní, o čom vypovedá aj etymológia slova (spicere - pozerat', intra - dovnútra, zvnútra). Interaktívny prístup je teda schopnostou vnútorného nazerania (Gáliková 2009, 1).

25 Na neoddelitel'nost času a priestoru v naratíve poukazujú rôzne koncepcie. M.-L. Ryanová v tejto súvislosti zdôrazňuje napr. Bachtinov polysémický koncept „chronotopu“, Werthov „textový svet“, Hermanov „príbehový svet“ alebo Genettovu „diegézu“ (Ryanová 2010, 38). Kategóriu času, ktorá je pre ponímanie kompozičnej kategórie priestoru bytostne dôležitá, je však v prípade jej vzájomnej súčinnosti s textom nutné vnímat trojako, teda jednak ako čas v texte, text v čase, ale aj ako čas mimo textu. V oboch románoch nie je čas v texte explicitne vymedzený, dochádza tu k prelínaniu časových línií, k ich narušeniu (ako výrazu fragmentárnosti textu), prípadne aj k absencii časových parametrov - v románe Pisár Gráč je výrazná minulost’ pretavená do spomienkovej formy (scény z vojnových frontov). Prelínanie špecifickej sujetovej reality so snovým svetom v románe Di̊m o tisíci patrech zase vedie k neurčitosti časovej línie. Avšak jednotlivé dejové epizódy sa konektujú s časom, v ktorom text vzniká a ku ktorému sa kontextovo vztahuje, a tak podla metodologického modelu kontextualizácie musíme brat’ do úvahy ešte aj d’alšiu kategóriu, a to čas mimo textu - ide o dobovú súčasnost', v ktorej text nielen vzniká, ale je aj prijímaný/ recipovaný. 
Pre náladový priestor záverečných kapitol Pisára Gráča je špecifický pokoj, ktorý nevytvára iba prítomnost protagonistov - dôverujúcich si ludí, ale aj predmety/rekvizity nachádzajúce sa okolo nich.

\begin{abstract}
„Čajová para celú izbu napĺn̆ala aromatickým pokojom, nevtieravé svetlo naznačovalo istú intimitu a diskrétnost', že sa tu povrávajú a povrávat'budú reči dôverujúcich si l’udí. [...] Pili sme čaj, sedeli sme, nechcelo sa nám rozchádzat’ a každú chvílu s očakávaním sme hladeli na Vilmu, čo povie a čo vykoná v tejto izbe, kde vari ešte nikdy nebolo útulno a veselo. Nábytok, koberce, lampy, obrazy i všetky drobničky do dnešného večera vytvárali dojem, že iba pred hodinou ich tu niekto rozostavil a ešte sa ich ničia dlaň nedotkla, nedarovala zariadeniu, izbe a všetkému, čo je v nej, to, čo jej nedal ani architekt, ani inštalatér, ani čalúnnik, ani ten, kto za zariadenie dával vel'ké peniaze, ani ten, kto ich prijímal“" (Hronský 1940, 211, 212; zvýraznila Z. CH.).
\end{abstract}

Naplnenie potreby mat’ pri sebe dôverného, blízkeho človeka sa odrazilo aj na zmene priestoru - izby, ktorá bola dovtedy iba prázdnou, prechodnou miestnostou bez majitela. Vymedzený priestor, kde aj priestorovým rekvizitám (nábytok, koberce, lampy, obrazy či drobničky) pribudol význam, je zároveň bodom završujúcim „cestu za ludmi“, pretože od tohto momentu sa protagonistom objavuje nádej pre možnost’ návratu $\mathrm{k}$ sebe, a teda aj otvorenosti k druhému človeku.

Ak sme hned' v úvode postulovali rozptýlenost’ autorského subjektu v konkrétnych textoch, spôsoby, akými J. C. Hronský a J. Weiss konštruujú epický priestor spolu s významovým využitím priestorových rekvizít, nemožno interpretovat bez akceptácie kontextov, ktoré sa podielali na výslednom charaktere individuálnych autorských poetík. Skutočnost', že literárny text nevnímame izolovane, potvrdzuje jeho vymedzenie v zmysle východiska, ale aj verifikátora našich interpretačných analýz, ktoré cez konkrétny text $\mathrm{v}$ konečnom dôsledku nezachytávajú iba autorský subjekt, ale taktiež dotvárajú výpoved' o charaktere medzivojnového sveta a od neho sa odvíjajúce osudy človeka v nových podmienkach vlastnej existencie. Takýmto spôsobom má autentická výpovedná hodnota románov Pisár Gráč a Dưm o tisíci patrech univerzálnejšiu platnost'.

\title{
SUMMARY
}

The aim of the submitted study is to clarify the specific shape of epic space and its props in selected literary works of the Slovak and Czech interwar modernism, and thus point out the individual character of poetics of Ján Weiss in the novel The House of a Thousand Floors (Dưm o tisíci patrech, 1929) and Jozef Cíger Hronský in the novel Gráč, the Scrivener (Pisár Gráč, 1940) in the wider Central European context - in a mutually identifying Czech and Slovak area. If we consider literary text a research basis and, in the end, also a verifier of interpretation analyses (Bátorová 2016, 2018a), the emphasis is put on a category of authenticity (author's personality) manifesting itself in a concrete character of the text (2011b), which is inevitably connected to a reflection of contexts of individual members of the communication triad Author-Text-Reader. Regarding the text analysis based on respecting an authentic author's style, the study is aimed at extending the symptomatics of literary modernism and affirming its relevance within the context of the Slovak and Czech interwar prose. Using the aforementioned approach, we exceed the limits of a strict time and character definition of literary modernism, opening up space for recapturing this multidimensional term in the area of the Slovak and Czech literary science. 


\section{LITERATÚRA}

Balabanovová, Christina, 1989. Česká moderna na pomezí literárních dějin a srovnávací typologie. In: Balabanovová, Christina - Pavlov, Ivan - Todorov, Veličko (eds.): Dějiny české literatury. Sofia: Nauka i izkustvo, 592-600.

Bátorová, Mária, 1992. Roky úzkosti a vzopätia. Bratislava: CAUSA editio.

Bátorová, Mária, 2000. J. C. Hronský a moderna (Mýtus a mytológia v literatúre). Bratislava: Veda.

Bátorová, Mária, 2004. Hrdina v slovenskej literárnej moderne a jeho typologické paralely. In: Koška, Ján (ed.): Hrdina $v$ stredoeurópskych a balkánskych literatúrach 19. a 20. storočia. Bratislava: Veda, 137 - 144.

Bátorová, Mária, 2011a. Slovenská literárna moderna v spektre svetovej moderny (Jozef Cíger Hronský). Martin: Matica slovenská.

Bátorová, Mária, 2011b. Stopy „autobiografie“ vo fikcii. Autentickost̉ diela Dominika Tatarku. In: World Literature Studies 2/3 (20), 46 - 60.

Bátorová, Mária, 2016. Autor, Text, Leser im Kontext. Komparatistik und Sozialwissenschaften. In: 21. svetový kongres medzinárodnej komparatistickej asociácie. 21. - 27. júl 2016, Universität Wien (ICLA). Panel Kabinetu Dionýza Ďurišina ÚFŠ [v tlači].

Bátorová, Mária, 2017. Vztah náboženstva a umenia v literatúre svetovej a slovenskej moderny. In: SLAVIA OCCIDENTALIS 73/2, 7 - 23.

Bátorová, Mária, 2018a. Nové metódy a možnosti výskumu v humanitných a spoločenských vedách. In: Akadémia - Správy SAV 54/5, 20 - 21.

Bátorová, Mária, 2018b. Pavol Strauss. In: Žilka, Tibor - Gallik, Ján (eds.): Pavol Srauss, prorok novej evanjelizácie. Gelnica: G-Ateliér, 205 - 213.

Benyovszky, Kristián, 2018. Teória umeleckej ilustrácie a metafora. In: World Literature Studies 3/10, 95 - 107.

Biedermann, Hans, 1992. Lexikón symbolov. Prel. Peter Dobrovodský - Silvia Varsiková. Bratislava: Obzor.

Blake, William, 2018. Obraz boží. In: Blake, William. Svět v zrnku pisku. https://web2.mlp.cz/ koweb/00/04/40/80/01/svet_v_zrnku_pisku.pdf. [cit. 20. 09. 2018].

Bourdieu, Piere, 2010. Pravidla umění. Geneze a struktura literárního pole. Prel. Petr Kyloušek Petr Dytrt. Brno: Host.

Čahojová-Bernátová, Božena, 2009. Pútnici a tuláci v umení 20. storočia. Štúdie, eseje o moderne a postmoderne. Bratislava: Tatran.

Čapek, Josef, 2018. Moderní výtvarný výraz. https://web2.mlp.cz/koweb/00/04/37/75/32/moderni_vytvarny_vyraz.pdf. [cit. 20.09.2018].

Čepan, Oskár, 1973. Literárny vývin v rokoch 1918 - 1945. In: Slovenská literatúra 20/3, 267 - 276.

Démuth, Andrej, 2008. Zrodenie subjektu z obrazu zrkadla. In: Heller, Daniel - Charvát, Michal Sobotková, Irena (eds.): Psychologické dny 2008: Já \& my a oni. Brno: FSpS - ČMPS. https:// cmps.ecn.cz/pd/2008/pdf/demuth.pdf. [cit. 20. 09. 2018].

Dvorský, Juraj, 2017. Od naratívnej gramatiky k interdisciplinarite naratívu. Ružomberok: Verbum.

Ďurišin, Dionýz, 1985. Teória literárnej komparatistiky. Bratislava: Slovenský spisovatel.'

Frajerová, Blanka, 2018. Známý neznámý Jan Zrzravý. Výstava podkládaná ze soukromých sbírek. https://www.lidovky.cz/kultura/znamy-neznamy-jan-zrzavy-vystava-poskladana-ze-soukromych-sbirek.A180413_110342_ln_kultura_jto. [cit. 01. 10. 2018].

Gadamer, Hans-Georg, 2010. Pravda a metoda I. Nárys filosofické hermeneutiky. Prel. David Mik. Praha: Triáda.

Gáfrik, Michal, 1993. Próza slovenskej moderny. Bratislava: Slovenský spisovatel. 
Gáliková, Silvia, 2009. Svet za zrkadlom. In: Kelemen, Jozef - Kvasnička, Vladimír - Rybár, Ján (eds.): Kognice a umělý život. Opava: Slezská univerzita v Opavě, 83 - 88.

Hronský, Jozef Cíger, 1940. Pisár Gráč. Turčiansky sv. Martin: Matica slovenská.

Hronský, Jozef Cíger, 2008. Prózy. Bratislava: Kalligram - Ústav slovenskej literatúry SAV.

Koška, Ján, 1998. Osobitost’ stredoeurópskeho medziliterárneho priestoru. In: Ďurišin, Dionýz (ed.): Medziliterárny centrizmus stredoeurópskych literatúr I. České Budejovice: Pedagogická fakulta Jihočeské univerzity, 39 - 49.

Little, Stephen, 2012. -izmy. Ako rozumiet umeniu. Prel. Viera Prokešová. Bratislava: Slovart.

Lotman, Jurij M., 1990. Štruktúra umeleckého textu. Prel. Milan Hamada. Bratislava: Tatran.

Mitka, Marek, 2017. Stredoeurópska próza moderny. Prešov: Prešovská univerzita v Prešove.

Nájemník, Václav. Jan Weiss: Tyfové horečky jako inspirace. https://www.rozhlas.cz/pred100lety/ cesi/_zprava/jan-weiss-tyfove-horecky-jako-inspirace--1577512?print=1\#. [cit. 04. 10. 2018].

Papoušek, Vladimír (ed.), 2010. Dějiny nové moderny. Česká literatura v letech 1905-1923. Praha: Academia.

Papoušek, Vladimír (ed.), 2014. Dějiny nové moderny. Česká literatura v letech 1924-1934: Lomy vertikál. Praha: Academia.

Papoušek, Vladimír (ed.), 2017. Dějiny „nové moderny. Česká literatura v letech 1935-1947. Praha: Academia.

Pokrivčáková, Silvia, 2002. Karnevalová a satirická groteska: Peter Jaroš, Dušan Dušek, Pavel Vilikovský, Peter Pištanek. Nitra: Garmond.

Ryanová, Marie-Laure, 2010. Narativní prostor. Prel. Veronika Čurdová. In: Aluze: revue pro literaturu, filozofii a jiné 14/3, 38 - 46.

Stanzel, Franz Karl, 1988. Teorie vyprávění. Prel. Jiří Stromšík. Praha: Odeon.

Tatarka, Dominik, 1943. Pach. In: Slovenské pohlady 59/6-7, 387 - 396.

Vojvodík, Josef, 2011. Magie data: psychoanalýza, fenomenologie a „čtvrtý rozměr". http://www. iliteratura.cz/Clanek/27951/papousek-vladimir-ed-dejiny-nove-moderny-ceska-literatura-vletech-19051923. [cit. 04. 10. 2018]

Weiss, Jan, 1964. Zrcadlo, které se opožduje. Praha: Československý spisovatel.

Weiss, Jan, 1966. Proč píši, tak jak píši. In: Čtenář 10.

Weiss, Jan, 1990. Dưm o tisíci patrech. Praha: Československý spisovatel.

Welsch, Wolfgang, 1994. Naše postmoderní moderna. Prel. Ivan Ozarčuk - Miroslav Petříček jr. Praha: Zvon.

\section{KONTAKT}

Mgr. Zuzana Chrenková

Ústav svetovej literatúry

Slovenská akadémia vied $\mathrm{v}$ Bratislave

Dúbravská cesta 9

84104 Bratislava

Slovenská republika

chrenkova.zuzka@gmail.com 